\title{
Geographical patterns of proportionate mortality for the most common causes of death in Brazil*
}

\author{
Variações geográficas no padrão de mortalidade proporcional por doenças \\ crônico-degenerativas no Brasil
}

Rosely Sichieri**, Cecilia A. de Lolio***, Valmir R. Correia**, James E. Everhart****

\begin{abstract}
SICHIERI, R. et al. Geographical patterns of proportionate mortality for the most common causes of death in Brazil. Rev. Saúde públ., S.Paulo, 26: 424-30, 1992. Mortality due to chronic diseases has been increasing in all regions of Brazil with corresponding decreases in mortality from infectious diseases. The geographical variation in proportionate mortality for chronic diseases for 17 Brazilian state capitals for the year 1985 and their association with socio-economic variables and infectious disease was studied. Calculations were made of correlation coefficients of proportionate mortality for adults of 30 years or above due to ischaemic heart disease, stroke and cancer of the lung, the breast and stomach with 3 socio-economic variables, race, and mortality due to infectious disease. Linear regression analysis included as independent variables the \% of illiteracy, $\%$ of whites, $\%$ of houses with piped water, mean income, age group, sex, and \% of deaths caused by infectious disease. The dependent variables were the $\%$ of deaths due to each one of the chronic diseases studied by age-sex group.

Chronic diseases were an important cause of death in all regions of Brazil. Ischaemic heart diseases, stroke and malignant neoplasms accounted for more than $34 \%$ of the mortality in each of the 17 capitals studied. Proportionate cause-specific mortality varied markedly among state capitals. Ranges were $6.3-19.5 \%$ for ischaemic heart diseases, $8.3-25.4 \%$ for stroke, $2.3-10.4 \%$ for infections and $12.2-21.5 \%$ for malignant neoplasm. Infectious disease mortality had the highest $(p<0.001)$ correlation with all the four socio-economic variables studied and ischaemic heart disease showed the second highest correlation $(p<0.05)$. Higher socio-economic level was related to a lower \% of infectious diseases and a higher \% of ischaemic heart diseases. Mortality due to breast cancer and stroke was not associated with socio-economic variables. Multivariate linear regression models explained 59\% of the variance among state capitals for mortality due to ischaemic heart disease, $50 \%$ for stroke, $28 \%$ for lung cancer, $24 \%$ for breast cancer and $40 \%$ for stomach cancer. There were major differences in the proportionate mortality due to chronic diseases among the capitals which could not be accounted for by the social and environmental factors and by the mortality due to infectious disease.
\end{abstract}

Keywords: Mortality, trends. Chronic disease, mortality. Cause of death. Residence characteristics.

\section{Introduction}

Proportionate mortality analysis has important applications to the health care system by showing

\footnotetext{
* Project supported by the CNPq (National Research Board). Processo 405948/82.

* "Centro de Ciências Biológicas e da Saúde da Universidade Estadual de Maringa" - Maringá, PR.

*** "Faculdade de Saúde Pública da Universidade de São Paulo" - São Paulo, SP.

**** Epidemiology and Data Systems Program, Division of Digestive Diseases and Nutrition, National Institute of Diabetes and Digestive and Kidney Diseases.
}

Reprints: R. Sichieri - Av. Colombo, 3690 - 87020 - 900. Maringá, PR. Brasil.

Publicação financiada pela FAPESP. Processo Saúde Coletiva 91/4994-0. the areas, population groups and age groups most suitable for the establishment of prevention programs. Also, proportionate mortality may give important clues for epidemiological research.

Mortality due to chronic diseases has increased in all regions of Brazil in the last 40 years ${ }^{1}$. However, Brazil shows great regional disparity for socio-economic indicators ${ }^{6}$ as well as for mortality 1,8 . North and Northeast regions have high mortality rates for infectious disease and low socio-economic status, whereas in the South and Southeast a higher socio-economic level is associated with lower mortality for infectious disease. Increased total mortality is often associated with a higher level of mortality due to infectious disease ${ }^{9}$.

The geographical differences for proportionate mortality among state capitals was determined for 
the leading causes of death in Brazil - ischaemic heart disease (IHD), cerebrovascular disease, here referred to as stroke and malignant neoplasms (MN). The association between cause specific proportionate mortality and socio-economic variables and proportionate mortality due to infectious and parasitic diseases (ID) is also analyzed.

\section{Material and Method}

Data on deaths for adults of 30 years of age or above were obtained from the publication of the Ministry of Health ${ }^{14}$ for the year 1985, the most recent year for which information has been published. The coding of underlying cause of death was done according to the Ninth Revision of the International Classification of Diseases (ICD) ${ }^{17}$, using the Brazilian short tabulation list for mortality ${ }^{15}$.

The state capitals were chosen as units of analysis because the quality of their data is presumed to be better than that of those for entire states. Nine state capitals with more than 8 per cent of deaths classified as due to ill-defined conditions were excluded from analysis, leaving 17 state capitals for analysis.

The 1980 Census was the source of data on socio-economic and environmental variables ${ }^{6}$. These data were not available for: "Porto Velho", "Macapá", "Maceíb" and "Campo Grande". For these state capitals pooled data were used instead from those cities, in each particular state of more than 100,000 inhabitants. Socio-economic data from the census included self-reported information on education level, race (skin color categorized as: white, black, mulatto, yellow), family earnings in terms of minimum salary (about $\$ 76$ a month in 1980) ${ }^{18}$, and piped water inside the house. The percentage of illiteracy, percentage of whites, percentage of houses with piped water, and mean income were the socio-economic variables included in the analysis for each state capital.

Proportionate mortality for IHD (ICD 410414), stroke (ICD 430-438), MN (ICD 140-208) and ID (ICD 001-139) were calculated by sex and by 10-year age groups (between 30 and 70 years or older), for each capital. In addition to overall MN the 3 leading sites of cancer: lung, stomach and breast were individually evaluated.

Percentage of ill-defined conditions of death were excluded from the total of deaths in the calculation of the proportions. Data on external causes (ICD E800-E999) were included for comparison because of their high occurrence for some of the state capitals studied.

Age-adjusted proportional mortality ratios
$(\mathrm{PMR})^{3}$ for each sex and capital were calculated by the formula:

$$
P M R=D / \stackrel{5}{\Sigma} J=1 t_{j}(d / o j)
$$

where:

$D$ is the total number of deaths by cause in a particular state capital:

ti is the age-specific number of deaths in that state capital;

dj is the number of deaths from the cause of interest for all 17 capitals, within an age interval j;

oj is the total number of deaths regardless of cause for all 17 state capitals, with the age interval j.

Association between causes of death was measured by the Spearman correlation coefficient. To determine how much of the geographical variation in chronic diseases was to be explained by socio-economic factors and by deaths from infectious disease, multivariate linear regression was performed taking into account the percentage of deaths caused by specific chronic diseases by age group as the dependent variable and age group, sex and percentage of deaths due to ID, 3 socio-economic variables and race as the independent variables. The dependent variable being a proportion an arcsine transformation of this variable should be carried out in order to minimize heteroscedasticity. Because this transformation did not change the results the original values were kept in the analysis. The statistical software used was SAS - Statistical Analysis System $^{20}$.

\section{Results}

In 1985, chronic diseases were important causes of death in all regions of Brazil. IHD, stroke and MN accounted for more than $34 \%$ of the mortality in each one of the 17 capitals studied, whereas in São Luis, Rio de Janeiro, and the 3 Southern capitals more than $50 \%$ of deaths were attributed to these three groups of diseases. There was considerable geographical variation in the proportions of mortality attributable to each disease. Ranges were $6.3-19.5 \%$ for ischaemic heart diseases, $8.3-25.4 \%$ for stroke, $2.3-10.4 \%$ for infections and $12.2-21.5 \%$ for malignant neoplasms (Table 1). This Table also shows important geographical variation in the proportional mortality due to ill-defined conditions of death and external causes. The proportion of deaths due to external causes was of about $9 \%$, except for Porto Velho where it accounted for $21 \%$, 92\% of whom were men.

Age-adjusted proportional mortality analysis 
Table 1. Number of deaths and crude proportionate mortality $(\%)$ due to stroke, ischaemic heart disease (IHD), malignant neoplasms (MN), infectious disease (ID), external causes and ill-defined conditions of death. Brazil, 1985.

\begin{tabular}{|c|c|c|c|c|c|c|c|c|}
\hline \multirow{2}{*}{ Region } & \multirow{2}{*}{ Capital } & \multirow{2}{*}{$\begin{array}{c}\text { Number of } \\
\text { Deaths }\end{array}$} & \multicolumn{6}{|c|}{ Percentage } \\
\hline & & & Stroke & IHD & MN & ID & External & lll-defined \\
\hline North & $\begin{array}{l}\text { P. Velho } \\
\text { Belém } \\
\text { Macapá }\end{array}$ & $\begin{array}{r}563 \\
3,938 \\
470\end{array}$ & $\begin{array}{r}13.8 \\
18.0 \\
8.3\end{array}$ & $\begin{array}{r}6.3 \\
11.9 \\
9.0\end{array}$ & $\begin{array}{l}14.2 \\
16.2 \\
20.5\end{array}$ & $\begin{array}{r}10.4 \\
5.8 \\
8.6\end{array}$ & $\begin{array}{r}21.0 \\
7.2 \\
10.2\end{array}$ & $\begin{array}{l}1.1 \\
2.3 \\
5.9\end{array}$ \\
\hline Northeast & $\begin{array}{l}\text { S. Luis } \\
\text { Teresina } \\
\text { Recife } \\
\text { Maceió } \\
\text { Salvador }\end{array}$ & $\begin{array}{l}2,059 \\
1,401 \\
6,516 \\
2,217 \\
6,697\end{array}$ & $\begin{array}{l}25.4 \\
19.1 \\
14.9 \\
21.5 \\
15.7\end{array}$ & \begin{tabular}{r|r|}
12.4 \\
11.9 \\
13.8 \\
13.6 \\
9.6
\end{tabular} & $\begin{array}{l}13.1 \\
13.5 \\
14.1 \\
12.2 \\
14.4\end{array}$ & $\begin{array}{l}8.5 \\
5.3 \\
5.9 \\
4.4 \\
7.4\end{array}$ & $\begin{array}{l}8.2 \\
8.9 \\
7.8 \\
8.7 \\
7.8\end{array}$ & $\begin{array}{l}3.4 \\
5.2 \\
2.2 \\
6.1 \\
1.4\end{array}$ \\
\hline Southeast & $\begin{array}{l}\text { B. Horizonte } \\
\text { Vitória } \\
\text { R. Janeiro } \\
\text { S. Paulo }\end{array}$ & $\begin{array}{r}8,897 \\
1,120 \\
36,576 \\
43,613\end{array}$ & $\begin{array}{l}14.5 \\
19.7 \\
15.8 \\
13.1\end{array}$ & $\begin{array}{l}10.6 \\
12.8 \\
18.4 \\
17.3\end{array}$ & $\begin{array}{l}17.0 \\
17.0 \\
17.0 \\
17.0\end{array}$ & $\begin{array}{l}4.3 \\
3.1 \\
2.3 \\
2.7\end{array}$ & $\begin{array}{r}6.8 \\
8.6 \\
7.3] \\
7.8\end{array}$ & $\begin{array}{l}7.9 \\
2.2 \\
2.0 \\
1.3\end{array}$ \\
\hline South & $\begin{array}{l}\text { Curitiba } \\
\text { Florianópolis } \\
\text { P. Alegre }\end{array}$ & $\begin{array}{r}5,362 \\
843 \\
6,703\end{array}$ & $\begin{array}{l}16.7 \\
18.6 \\
13.3\end{array}$ & $\begin{array}{l}18.9 \\
16.7 \\
19.5\end{array}$ & $\begin{array}{l}18.6 \\
21.5 \\
21.5\end{array}$ & $\begin{array}{l}2.7 \\
2.3 \\
2.4\end{array}$ & $\begin{array}{l}8.9 \\
8.3 \\
6.6\end{array}$ & $\begin{array}{l}1.0 \\
2.5 \\
1.7\end{array}$ \\
\hline Midwest & $\begin{array}{l}\text { C. Grande } \\
\text { D. Federal }\end{array}$ & $\begin{array}{l}1,507 \\
3,491\end{array}$ & $\begin{array}{l}14.5 \\
11.5\end{array}$ & $\begin{array}{r}13.9 \\
9.0\end{array}$ & $\begin{array}{l}14.9 \\
17.0\end{array}$ & $\begin{array}{l}4.7 \\
9.2\end{array}$ & $\begin{array}{l}11.3 \\
11.6\end{array}$ & $\begin{array}{l}2.2 \\
1.5\end{array}$ \\
\hline
\end{tabular}

Table 2. Age-adjusted proportional mortality ratio for infectious and parasitic diseases (ID), ischaemic heart disease (IHD), stroke, malignant neoplasms (MN), lung, stomach and breast cancer, by sex, for 17 Brazilian state capitals, 1985.

\begin{tabular}{|c|c|c|c|c|c|c|c|c|}
\hline Capital & Sex & ID & IHD & Stroke & $M N$ & Lung & Stomach & Breast \\
\hline $\begin{array}{l}\text { Porto Velho } \\
\text { Belém } \\
\text { Macapá } \\
\text { São Luís } \\
\text { Teresina } \\
\text { Recife } \\
\text { Maceí́ } \\
\text { Salvador } \\
\text { Belo Horizonte } \\
\text { Vitória } \\
\text { Rio de Janeiro } \\
\text { São Paulo } \\
\text { Curitiba } \\
\text { Florianópolis } \\
\text { Porto Alegre } \\
\text { Campo Grande } \\
\text { Distrito Federal }\end{array}$ & $\begin{array}{l}\text { men } \\
\text { women } \\
\text { men } \\
\text { women } \\
\text { men } \\
\text { women } \\
\text { men } \\
\text { women } \\
\text { men } \\
\text { women } \\
\text { men } \\
\text { women } \\
\text { men } \\
\text { women } \\
\text { men } \\
\text { women } \\
\text { men } \\
\text { women } \\
\text { men } \\
\text { women } \\
\text { men } \\
\text { women } \\
\text { men } \\
\text { women } \\
\text { men } \\
\text { women } \\
\text { men } \\
\text { women } \\
\text { men } \\
\text { women } \\
\text { men } \\
\text { women } \\
\text { men } \\
\text { women }\end{array}$ & $\begin{array}{r}2.33 \\
2.51 \\
1.58 \\
1.72 \\
2.40 \\
2.31 \\
2.27 \\
2.38 \\
1.45 \\
1.46 \\
1.69 \\
1.67 \\
1.17 \\
1.22 \\
2.22 \\
1.71 \\
1.15 \\
1.18 \\
0.77 \\
0.95 \\
0.70 \\
0.68 \\
0.74 \\
0.76 \\
0.76 \\
0.69 \\
0.55 \\
0.87 \\
0.67 \\
0.69 \\
1.26 \\
1.19 \\
2.04 \\
2.55\end{array}$ & $\begin{array}{l}0.43 \\
0.49 \\
0.74 \\
0.73 \\
0.53 \\
0.62 \\
0.93 \\
0.62 \\
0.72 \\
0.79 \\
0.90 \\
0.81 \\
0.93 \\
0.80 \\
0.61 \\
0.62 \\
0.70 \\
0.63 \\
0.80 \\
0.80 \\
1.13 \\
1.12 \\
1.06 \\
1.10 \\
1.10 \\
1.29 \\
0.99 \\
1.03 \\
1.17 \\
1.20 \\
0.86 \\
0.91 \\
0.71 \\
0.57\end{array}$ & $\begin{array}{l}1.18 \\
0.88 \\
1.18 \\
1.23 \\
0.54 \\
0.59 \\
1.65 \\
1.79 \\
1.25 \\
1.32 \\
1.02 \\
0.97 \\
1.43 \\
1.49 \\
0.96 \\
1.14 \\
1.03 \\
0.94 \\
1.43 \\
1.24 \\
1.01 \\
1.05 \\
0.92 \\
0.87 \\
1.19 \\
1.07 \\
1.18 \\
1.30 \\
0.88 \\
0.89 \\
0.99 \\
1.03 \\
0.78 \\
0.80\end{array}$ & $\begin{array}{l}0.84 \\
1.10 \\
1.00 \\
0.97 \\
1.36 \\
1.27 \\
0.68 \\
0.93 \\
0.66 \\
0.97 \\
0.76 \\
0.92 \\
0.72 \\
0.76 \\
0.86 \\
0.87 \\
0.99 \\
1.07 \\
0.85 \\
1.21 \\
1.00 \\
0.95 \\
1.03 \\
1.03 \\
1.12 \\
1.09 \\
1.34 \\
1.33 \\
1.26 \\
1.30 \\
0.93 \\
0.87 \\
0.99 \\
0.93\end{array}$ & $\begin{array}{l}0.67 \\
1.58 \\
1.02 \\
0.88 \\
0.81 \\
0.52 \\
0.76 \\
0.65 \\
0.54 \\
0.14 \\
0.73 \\
0.65 \\
0.87 \\
0.50 \\
0.63 \\
0.80 \\
0.71 \\
0.77 \\
0.72 \\
1.08 \\
1.17 \\
1.17 \\
0.95 \\
0.97 \\
0.79 \\
1.17 \\
1.54 \\
0.26 \\
1.82 \\
1.52 \\
1.04 \\
0.88 \\
0.78 \\
0.87\end{array}$ & $\begin{array}{l}1.93 \\
0.84 \\
1.89 \\
1.12 \\
3.57 \\
1.09 \\
0.87 \\
1.06 \\
0.38 \\
0.65 \\
0.58 \\
0.54 \\
0.71 \\
0.39 \\
0.61 \\
0.89 \\
1.18 \\
1.13 \\
0.89 \\
0.83 \\
0.87 \\
0.92 \\
1.09 \\
1.10 \\
1.25 \\
1.06 \\
1.75 \\
1.12 \\
0.75 \\
1.20 \\
0.98 \\
1.05 \\
1.06 \\
1.36\end{array}$ & $\begin{array}{l}0.56 \\
0.67 \\
0.61 \\
0.73 \\
0.75 \\
0.91 \\
0.62 \\
0.77 \\
1.19 \\
1.37 \\
0.93 \\
1.16 \\
1.14 \\
1.09 \\
1.30 \\
0.73 \\
0.62\end{array}$ \\
\hline
\end{tabular}


showed geographical differences for all the causes of death studied and for both sexes (Table 2). Stomach cancer among men had the highest ratio variation ranging from a ratio of observed over expected number of deaths of 0.38 for Terezina to 3.57 for Macapá. The South and Southeast had lower risk for ID mortality with the ratios for these capitals being all lower than one, whereas the ratios for IHD were the highest (Table 2).

Socio-economic indicators also showed important differences in geographical distribution (Table 3). Ranges were 9.0-32.6\% illiteracy, 14.992.4\% white, 1.9-5.0 mean income and 24.583.5\% piped water.

The Spearman correlation coefficient for ID mortality was negative and highly significant $(p<$ 0.001 ) for IHD and stroke; whereas this association for lung and stomach cancer was significant only for men, being positive for stomach cancer and negative for lung cancer (Table 4).

Mortality for ID was negatively correlated with race and the three socio-economic variables studied, being positively correlated to the percentage of illiteracy and negatively related to the percentage of white population, the percentage of households with piped water and mean income. Ischaemic heart disease showed the second highest correlation $(p<0.05)$ for race and the 3 socioeconomic variables, being negatively correlated to illiteracy and positively correlated to the other variables.

Breast cancer and stroke were not associated with socio-economic variables (Table 5). Illiteracy was the variable most correlated with all diseases. Its association with the proportionate mortality was quadratic for ID and IHD (Figure) and linear for the other diseases.

Table 3. Socio-economic indicators for state capitals. Brazil, $1985^{6}$.

\begin{tabular}{lrrrr}
\hline $\begin{array}{l}\text { State } \\
\text { Capital }\end{array}$ & $\begin{array}{c}\% \\
\text { lliteracy }\end{array}$ & $\begin{array}{c}\% \\
\text { White }\end{array}$ & $\begin{array}{c}\text { Mean Income } \\
\text { (Minimum Wage) }\end{array}$ & $\begin{array}{c}\text { \% } \\
\text { Piped Water }\end{array}$ \\
\hline Porto Velho* & 29.1 & 32.0 & 2.6 & 24.5 \\
Belém & 9.0 & 27.2 & 2.9 & 61.7 \\
Macapa" & 21.7 & 23.7 & 2.5 & 65.7 \\
São Luís & 16.3 & 28.5 & 2.2 & 63.3 \\
Teresina & 30.1 & 14.9 & 1.9 & 47.7 \\
Recife & 23.5 & 38.2 & 2.8 & 49.6 \\
Maceió & 32.6 & 36.1 & 2.3 & 60.5 \\
Salvador & 16.2 & 24.6 & 3.7 & 64.8 \\
Belo Horizonte & 12.1 & 55.6 & 3.7 & 61.8 \\
Vitória & 13.7 & 49.6 & 3.3 & 73.3 \\
Rio Janeiro & 10.6 & 61.3 & 5.1 & 83.5 \\
Sáo Paulo & 11.1 & 71.8 & 5.0 & 71.3 \\
Curitiba & 10.5 & 77.5 & 3.6 & 78.6 \\
Florianópolis & 10.9 & 92.4 & 3.8 & 77.5 \\
Porto Alegre & 9.1 & 86.0 & 3.8 & 40.3 \\
Campo Grande* & 14.6 & 62.6 & 3.7 & 80.2 \\
Distrito Federal & 11.4 & 53.8 & 4.6 & \\
\hline
\end{tabular}

- Pooled data from cities with more than 100,000 inhabitants.

Table 4. Spearman correlation coefficients for proportionate mortality due to ischaemic heart disease (HDD), stroke, infectious and parasitic disease (ID), malignant neoplasms (MN), lung, stomach and breast cancer, by sex, for 17 Brazilian state capitals, 1985.

\begin{tabular}{lcccccc}
\hline & IHD & Stroke & ID & MN & Lung & Stomach \\
\hline Women & \multicolumn{7}{c}{ Men } \\
\hline IHD & & $0.53^{* *}$ & $-0.46^{* *}$ & $0.41^{* *}$ & $0.64^{* *}$ & 0.16 \\
Stroke & $0.37^{* *}$ & & $-0.33^{* *}$ & $0.29^{* *}$ & $0.31^{* *}$ & 0.10 \\
ID & $-0.61^{* *}$ & $-0.55^{* *}$ & & 0.13 & $-0.25^{*}$ & $0.27^{* *}$ \\
MN & -0.13 & -0.14 & 0.15 & & $0.46^{* *}$ & $0.34^{* *}$ \\
Lung & 0.19 & -0.02 & -0.05 & $0.23^{*}$ & & $0.31^{* *}$ \\
Stomach & 0.05 & -0.06 & 0.10 & $0.31^{* *}$ & $0.26^{*}$ & \\
Breast & $-0.24^{*}$ & $-0.23^{*}$ & -0.008 & $0.50^{* *}$ & 0.12 & -0.02 \\
\hline
\end{tabular}

- $0.001<p<0.05$

* $p<0.001$ 
Table 5. Age-sex adjusted ${ }^{+}$Spearman correlation coefficients for proportionate mortality due to ischaemic heart disease (IHD), stroke, infectious and parasitic diseases (ID), malignant neoplasms (MN), lung, stomach and breast cancer, with socio-economic factors, for 17 Brazilian State capitals, 1985

\begin{tabular}{lcccc}
\hline Cause & $\begin{array}{c}\% \\
\text { Illiteracy }\end{array}$ & $\begin{array}{c}\% \\
\text { White }\end{array}$ & $\begin{array}{c}\% \\
\text { Piped Water }\end{array}$ & $\begin{array}{c}\text { Mean } \\
\text { income }\end{array}$ \\
\hline IHD & $-0.20^{* *}$ & $0.30^{* *}$ & $0.18^{*}$ & $0.18^{* *}$ \\
Stroke & -0.04 & 0.03 & -0.10 & -0.05 \\
ID & $0.35^{* *}$ & $-0.50^{* *}$ & $-0.30^{* *}$ & $-0.29^{* *}$ \\
MN & $-0.16^{*}$ & 0.11 & $0.17^{*}$ & 0.03 \\
Lung & $-0.18^{* *}$ & $0.15^{*}$ & 0.09 & 0.12 \\
Stomach & $-0.16^{*}$ & 0.09 & 0.10 & -0.06 \\
Breast & -0.06 & 0.08 & 0.07 & 0.05 \\
\hline
\end{tabular}

+ By stratifying analyses by sex and 10 -year age group $0.001<p<0.05$

** $p<0.001$
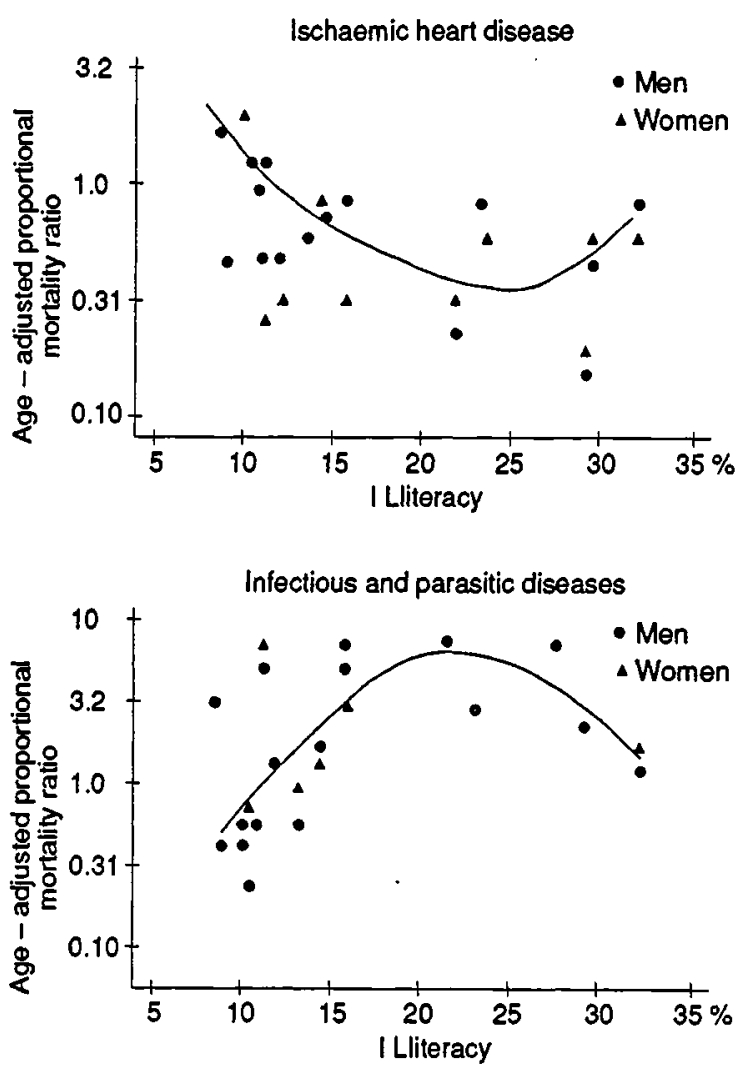

Figure. Age-adjusted proportionate mortality ratio for 17 Brazilian state capitals by percentage of illiteracy.

Differences in the geographical distribution of the causes of deaths were partially accounted for by socio-economic factors. Multivariate linear regression models explained $59 \%$ of the variance for mortality among state capitals due to IHD, 50\%
Table 6. Beta coefficient and standard errors for infectious disease mortality. Models adjusted for sex, age group, $\%$ illiteracy, \% whites, \% piped water, and mean income.

\begin{tabular}{lccrr}
\hline \multirow{2}{*}{ Cause } & \multicolumn{3}{c}{ Infectious disease } & \\
\cline { 2 - 4 } & $\begin{array}{c}\text { Beta } \\
\text { coefficient }\end{array}$ & $\begin{array}{c}\text { Standard } \\
\text { Error }\end{array}$ & p. value & $\begin{array}{r}\mathrm{R}^{2} \text { of the } \\
\text { model }^{*}\end{array}$ \\
\hline IHD** & -0.20 & 0.09 & 0.03 & 0.59 \\
Stroke & -0.43 & 0.11 & 0.0002 & 0.50 \\
Lung cancer & 0.05 & 0.04 & 0.18 & 0.28 \\
Stomach cancer & 0.24 & 0.04 & 0.0001 & 0.24 \\
Breast cancer & -0.27 & 0.07 & 0.0006 & 0.40 \\
\hline
\end{tabular}

- Amount of variance in proportionate mortality between state capitals explained by the variables in the multiple linear regression.

* Ischaemic heart disease.

for stroke, $40 \%$ for stomach cancer, $28 \%$ for lung cancer, $24 \%$ for breast cancer (Table 6).

\section{Discussion}

Our findings show the importance of chronic disease mortality in all the state capitals studied. The percentages for chronic disease mortality in Brazil are in between the percentages for developing countries and developed ones ${ }^{9}$. Declining fertility and mortality have caused the median age of the population to increase in Brazil ${ }^{19}$, shifting the dominant public health problems from infant mortality and infectious disease to chronic disease mortality. Public health strategies for dealing with most of the risk factors for chronic diseases have not been implemented in Brazil. Modifications of risk factors such as smoking, obesity, alcohol consumption, and blood pressure should have an important impact on the reduction of chronic disease mortality, as shown in a simulation study for developing countries ${ }^{5}$ and in studies related to stroke mortality 11,12 .

Reservations concerning the quality of data must be kept in mind in the analysis of our results. Only those areas with better quality data have been studied, by including in the analysis only the capitals and by excluding cities with more than $8 \%$ of ill defined conditions of death. These conditions have been excluded from the total by assuming that their distribution is similar to that of the known causes of death ${ }^{10}$. Limitation of ecological analysis to the study associations between possible risk factors and diseases ${ }^{13}$ should also be noted. The major limitation of ecologic analysis is the potential for bias in the effect estimation. This fact occurs when an ecologic predictor variable has a 
different association at the individual level than at the overall population level ${ }^{13}$. Also in ecologic analysis the absolute value of the correlation coefficient may be modified by grouping ${ }^{13}$.

Despite possible biases, the magnitude of the variations found suggest that they are not related to study design or accuracy of death certificates. For example, the stomach cancer age-adjusted proportional mortality ratio ranged from 0.38 to 3.57 for men. Such a large difference suggests differences in the prevalence of risk factors. Further, our findings are consistent with those from other countries, where cancer of the lung and stomach predominate among men $\mathrm{m}^{4,21}$ and stroke mortality is higher among women than men $^{21}$. Negative associations between stomach cancer and socio-economic factors have been observed in other countries ${ }^{7}$ and in other analyses of mortality in Brazil ${ }^{16}$. Our findings are also in accordance with the literature for the association found between socio-economic factors and infectious disease ${ }^{9}$ and $\mathrm{IHD}^{2,9}$.

Proportionate mortality may be highly influenced by the competition between causes of death, ID, and external cause mortality, potentially reducing the percentage due to chronic diseases. Data from Porto Velho showed that $21 \%$ of deaths were due to external causes and this capital also had the lowest percentage due to IHD. For external causes this problem should be important only among men, since more than $80 \%$ of the deaths in those cities with a higher percentage due to external causes occurred among men.

The present study indicates that the major differences in the proportionate mortality due to chronic diseases among the Brazilian capitals can not be accounted for either by social and environment factors or by infectious disease mortality. Studies should be undertaken in the search for specific risk factors that may explain the geographical variations found for chronic diseases. Also, since the proportional mortallity for IHD, stroke and breast cancer is high and negatively associated with ID mortality, as social conditions improve and ID continues to decline, chronic diseases will have increasing important health implications.

SICHIERI, R. et al. Variações geográficas no padrão de mortalidade proporcinal por doenças crônico-degenerativas no Brasil. Rev. Saúde públ., S.Paulo, 26: 424-30, 1992. Em razão de a mortalidade por doenças crônicodegenerativas estar aumentando no Brasil, com correspondente redução das doenças infecciosas, foi realizado estudo comparativo entre 17 capitais brasileiras em relação à mortalidade proporcional para as principais causas de morte em 1985. Foram calculados coeficientes de correlação entre a mortalidade proporcional decorrente de doença isquêmica do coração, doença cerebrovascular, câncer de pulmão, mama e estômago e 3 variáveis socioeconômicas, raça e a mortalidade proporcional por doenças infecciosas. A análise multivariada através de regressão linear incluiu como variáveis independentes os percentuais de: analfabetismo, casas com instalação domiciliar de água, renda média, população da cor branca, faixa etária e sexo. As variáveis dependentes foram as percentagens de óbito devido a cada uma das doenças crônicodegenerativas em estudo, por grupo de idade e sexo. Os resultados mostraram que as doenças crônico-degenerativas são importantes causas de morte em todas as regiōes do país. A doença isquêmica do coração, a doença cerebrovascular $e$ as neoplasias malignas foram responsáveis por mais do que $34 \%$ da mortalidade em todas as capitais estudadas. A mortalidade proporcional variou de forma marcante entre as capitais estudadas, com amplitudes de variação de $6,3-19,5 \%$ para a doença isquêmica do coração, 8,3-25,4\% para a doença cerebrovascular, 2,3$10,4 \%$ para infeç̧ões e $12,2-21,5 \%$ para as neoplasias malignas. A mortalidade proporcional por infecções apresentou a maior correlação com os indicadores socioeconômicos $(p<0,001)$, sendo acompanhada pela doença isquêmica do coração $(p<0,05)$. $O$ alto nível socioeconômico relacionou-se com menor percentagem de mortalidade por infecçōes e mais alta percentagem de doença isquêmica do coração, enquanto que a mortalidade por doença cerebrovascular e câncer de mama não se associaram com os indicadores socioeconômicos. Os modelos de análise multivariada explicaram $59 \%$ da variação entre as capitais, para a doença isquêmica do coração, $50 \%$ para a doença cerebrovascular, $28 \%$ para o câncer de pulmão, $24 \%$ para o câncer de mama e $40 \%$ para o câncer de estômago. As importantes diferenças geográficas encontradas para a mortalidade proporcional devido às doenças crônico-degenerativas não podem ser totalmente explicadas pela variação na mortalidade por doenças infecciosas e pelos fatores socioeconômicos estudados, sugerindo a existência de fatores de risco específicos.

Descritores: Mortalidade, tendência. Doença crônica, mortalidade. Causa de morte. Distribuição espacial.

\section{Referências Blbliográficas}

1. BECKER, R.A. et al. Investigaçōes sobre perfis de saúde: Brasil. 1984. Brasília, Centro de Documentação do Ministério da Saúde, 1989.

2. BRENNER, M.H. Mortality and economic instability: detailed analyses for selected industrialized countries. Int. J. Hith serv., 13: 563-620, 1983.

3. BRESLOW, N.E. \& DAY, N.E. Statistical methods in cancer research. Lyon, World Health Organization, 1980. v.2, p. 76-9. (IARC - Scientific Publications n ${ }^{2} 32$ ).

4. DOCKERTY, J.D. et al. Stomach cancer in New Zealand: time trends, ethnic group differences and a cancer registry based case-control study. Int. J. Epidem., 20: 45-53, 1991.

5. DOWD, J.E. \& MANTON, K.G. Forecasting chronic disease risk factors in developing countries. Int. J. Epidem., 19: 1091-36, 1990.

6. FUNDAÇÃO IBGE. Indicadores sociais: regiōes metropolilanas, aglomeraçōes urbanas, municípios com mais de 100.000 habitantes. Rio de Janeiro, 1988. 
7. FUNDAÇÃO OSWALDO CRUZ. Escola Nacional de Saúde Pública. Câncer mortalidade no Brasil. Dados RADIS, 1991.

8. FUNDAÇÃO OSWALDO CRUZ. Escola Nacional de Saúde Pública. Estrutura da mortalidade em 1979. Dados RADIS, 1: 1-8, 1983.

9. HAKULINEN, T. et al. Global and regional mortality pattems by cause of death in 1980. Int. J. Epidemiol., 15: 227-33, 1986.

10. LAURENTI, R. et al. Estatístices de saúde. São Paulo, EPU, 1985.

11. LOLIO, C.A. \& LAURENTI, R. Tendência da mortalidade por doenças cerebrovasculares em adultos maiores de 20 anos de idade no Município de São Paulo (Brasil) 1950 a 1981. Rev. Saúde públ., S.Paulo, 20: 343-6, 1986.

12. MARMOT, M.G. \& SMITH, G.D. Why are Japanese living longer? Brit. med. J., 299: 1547-51, 1989.

13. MATOS, E.L. et al. Geographical pattem of cancer mortality in Argentina. Int. J. Epidem., 19: 860-70, 1990.

14. MINISTERIO DA SAUDE. Estatisticas de mortalidade, Brasil, 1985. Brasilia, Centro de Documentação, 1988.

15. MINISTERIO DA SAUDE. Secretaria Nacional de Açōes Básicas. Divisão Nacional de Epidemiologia. Lista bres. ileira para a mortalidade. Brasilia, 1987. (Série G: Estatísticas e informaçoes para a saúde).

16. MORGENSTERN, $\mathrm{H}$. Uses of ecologic analysis in epidemiologic research. Amer.J. publ. Hlth, 72: 133-44, 1982.

17. ORGANIZAÇÃO MUNDIAL DA SAÚDE. Manual de classificação estatística intemacional de doenças, lesões e causas de óbito; 9 rev., 1975. São Paulo, Centro da OMS para Classificaçâo de Doenças em Português, 1980. v. 1.

18. PREÇOS, Salários, Suprimentos. Conj. econom., 40 (10): 16-32, 1986.

19. RAMOS, L.R. et al. Envelhecimento populacional: uma realidade brasileira. Rev. Saúde públ, S.Paulo, 21: 211$24,1987$.

20. SAS INSTITUTE INC. SAS user's guide: statistics; version 5. Cary, NC, 1985.

21. SUTHERLAND, J.E. et al. Proportionate morality trends: 1950 through 1986. J. Amer. med. Assoc., 264: 317884, 1990.

Recebido para publicaçâo em 25.3.1992

Reapresentado em 18.9.1992 Aprovado para publicação em 23.10.1992 